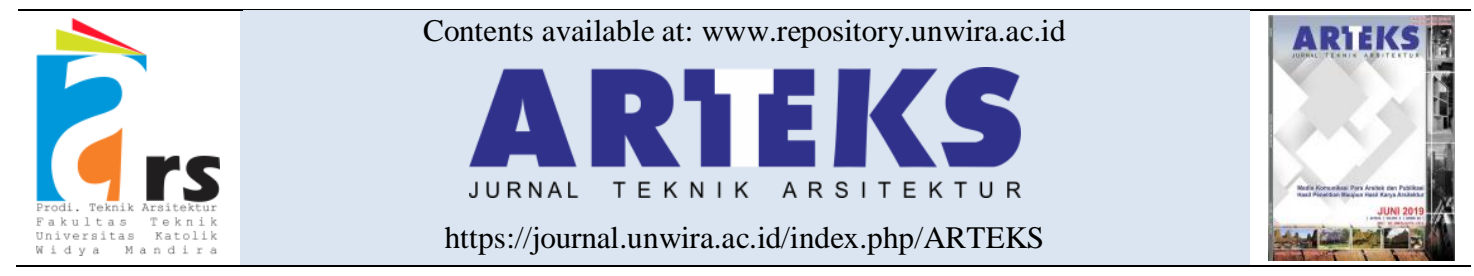

Research paper

doi: http://doi.org/10.30822/arteks.v5i2.436

\title{
Persepsi atribut pedagang kaki lima terhadap pemanfaatan trotoar Pandanaran
}

\author{
Alfanadi Agung Setiyawan*, Suzanna Ratih Sari, Agung Budi Sardjono \\ Program Studi Magister Arsitektur, Fakultas Teknik, Universitas Diponegoro \\ Jl. Prof. Soedharto, SH., Tembalang, Semarang, Indonesia
}

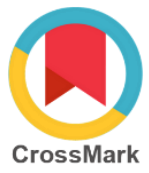

\begin{tabular}{l}
\hline ARTICLE INFO \\
\hline Article history: \\
Received March 03, 2020 \\
Received in revised form March 27, \\
2020 \\
Accepted April 26, 2020 \\
Available online August 01, 2020
\end{tabular}

Keywords:
Attributes
Behavior
Perception
Sidewalk
Street vendors
*Corresponding author: Alfanadi Agung
Setiyawan
Program Studi Magister Arsitektur, Fakultas
Teknik, Universitas Diponegoro, Indonesia
Email: alfanadisetiyawan@gmail.com

Keywords

Attributes

Behavior

Perception

Sidewalk

Street vendors

\section{Pendahuluan}

Trotoar atau pedestrian ways adalah jalur sirkulasi khusus yang diperuntukkan bagi pejalan. Trotoar merupakan salah satu prasarana road group atau kelompok jalan (Grigg 1988). Prasarana jalan ini kedudukannya di dalam perancangan kota adalah bersinergi dengan sistem transportasi perkotaan secara menyeluruh (Wardianto et al. 2012). Sistem tersebut seperti jalan kendaraan bermotor, JPO (jembatan penyeberangan orang), halte bus, dan terminal. Selain itu, trotoar juga menunjang perkembangan dan efektivitas dari sebuah kawasan atau dikenal dengan istilah activity support (Sirvani 1985). Sehingga, perencanaan trotoar mengikuti eksisting koridor jalan yang telah ada dengan tujuan mewadahi kegiatan yang sedang berlangsung pada koridor tersebut.

Seiring berjalannya waktu dan tuntutan akan ruang, trotoar tidak lagi sepenuhnya memberikan rasa aman dan nyaman kepada penggunanya (Mberu and Purbadi 2018). Sering terjadi konflik perebutan ruang gerak antara pejalan kaki dan pengguna trotoar lainnya khususnya PKL (pedagang kaki lima) atau hawkers yang bermakna penjaja barang dan jasa di tempat umum (McGee and Yeung 1977; Fryer 1982). Meskipun telah ada regulasi dan berulangkali pula ditertibkan, akan tetapi PKL tetap kembali berdagang pada trotoar yang sama dan jumlahnya cenderung bertambah. Kondisi fisik trotoar yang 
sempit serta minimnya fasilitas yang dapat diakses PKL seperti pada koridor Pandanaran Semarang, tidak serta merta mengurangi minat PKL untuk datang berdagang (Lihat gambar 1).
Dengan lebar kotor hanya 3,5 meter, PKL tetap menempatkan diri di bawah naungan pohon, tiang lampu, halte, bahkan JPO.

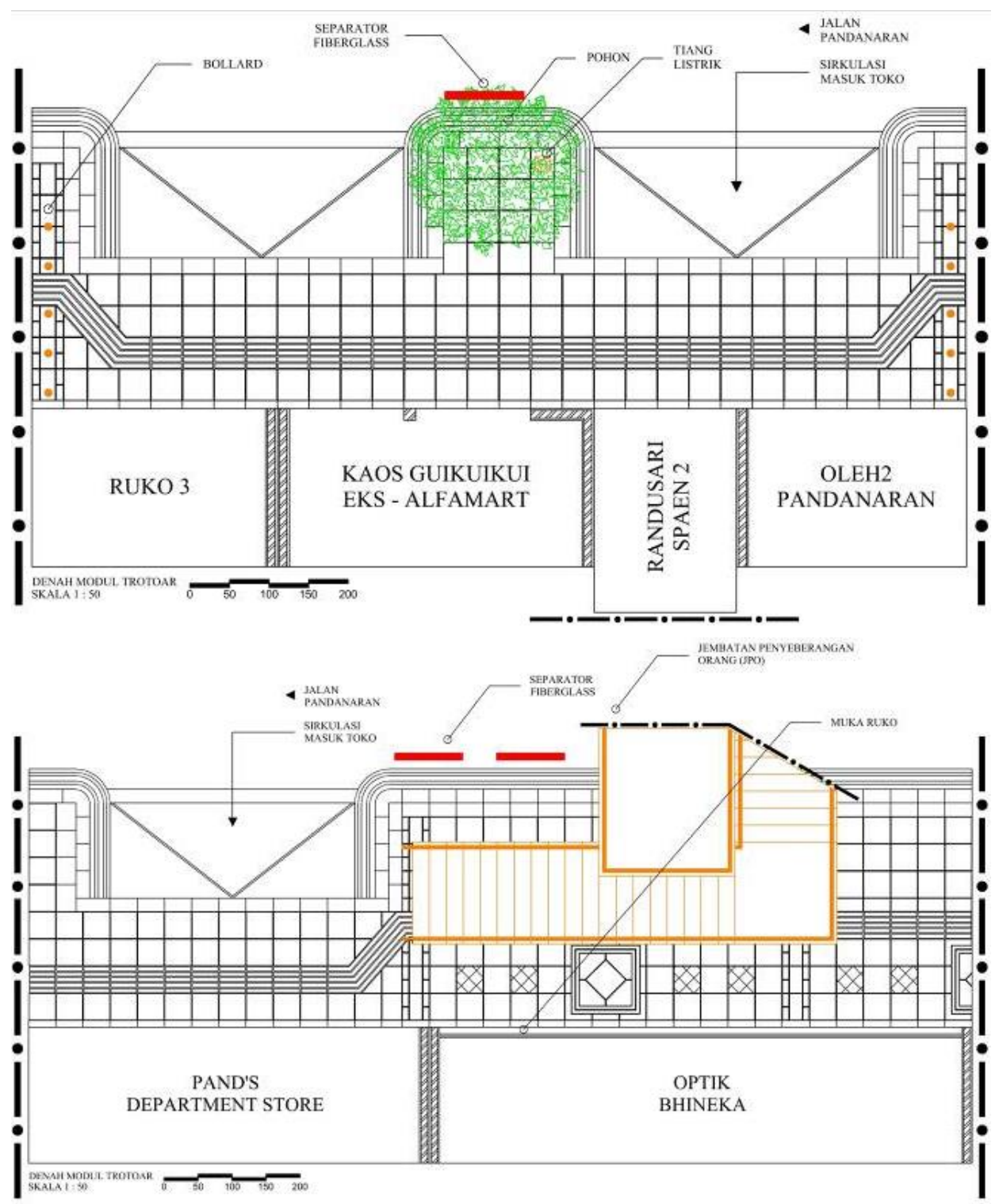

Gambar 1. Bentuk trotoar koridor Jalan Pandanaran

Koridor Jalan Pandanaran merupakan salah satu jalan protokol yang cukup padat di kota Semarang, sebagai salah satu koridor jalan memanjang yang mewadahi segala pekerjaan sektor formal seperti bisnis dan perdagangan kota Semarang (Lihat gambar 2). Pada awalnya koridor Jalan Pandanaran ini diperuntukkan untuk area bisnis dan perkantoran, sementara area komersial hanya terdiri dari beberapa pusat oleh- oleh. Kemudian seiring berjalannya waktu, pusat oleh-oleh yang secara kuantitas hanya segelintir ini berbalik mendominasi koridor Pandanaran dan memunculkan bangunan komersial lain seperti restoran cepat saji, toko roti, minimarket dan sejenisnya sehingga mengundang PKL untuk ikut serta meraup pendapatan di koridor Pandanaran dengan berdagang di trotoarnya. 


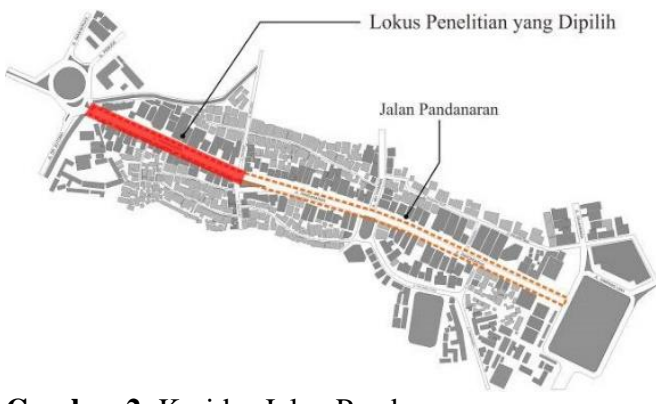

Gambar 2. Koridor Jalan Pandanaran
Berdasarkan pengamatan lapangan pada tanggal 3 dan 4 Desember 2019 diperoleh sejumlah 33 PKL yang aktif berdagang dengan waktu dagang yang beragam. Untuk mempermudah pengamatan, koridor Jalan Pandanaran dibagi menjadi tiga zona: Zona A, B, dan C (Lihat gambar 3). Pembagian zona ini didasarkan hasil observasi lapangan yang mengacu pada persebaran PKL disepanjang trotoar, dimana tiap zona dibatasi oleh keberadaan jalan kecil atau JPO (Jembatan Penyeberangan Orang).

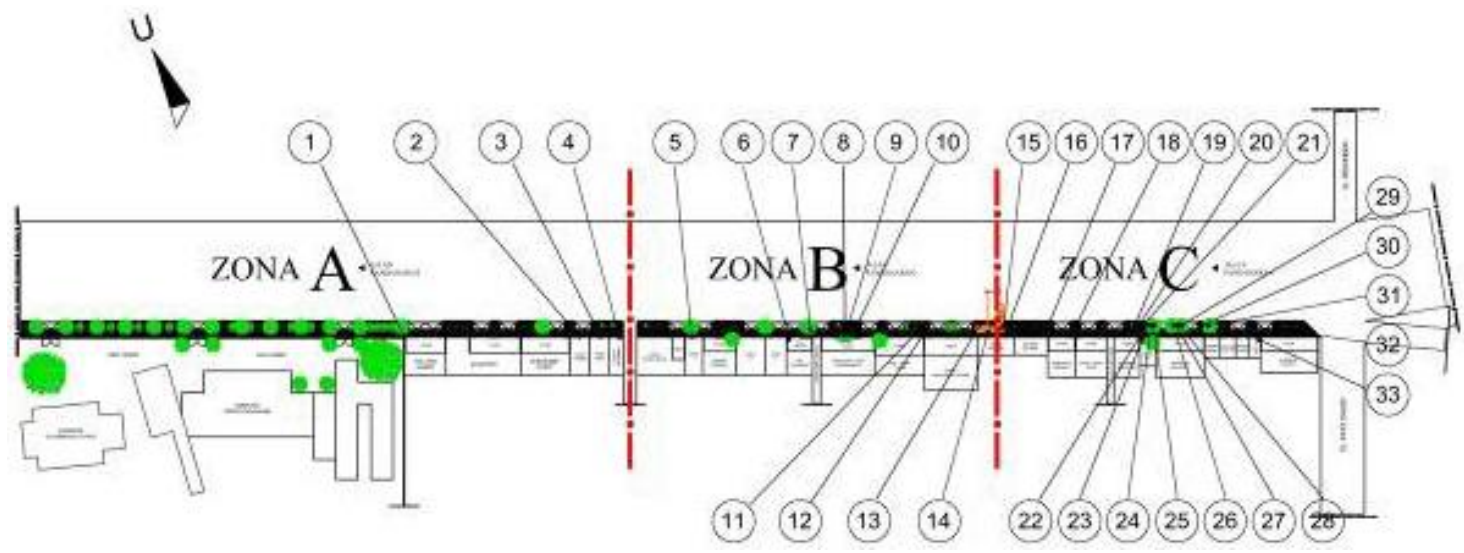

Gambar 3. Zonasi persebaran PKL koridor Jalan Pandanaran

Susunan benda atau properti dalam suatu setting akan memberikan stimulus bagi penggunanya. Dimulai dari proses penginderaan kemudian diintegrasikan otak untuk kemudian dimaknai menurut pengalaman masing-masing pengguna (Sarwono 1992). Proses integrasi di atas dinamakan persepsi, dimana proses tersebut menghasilkan makna mengenai properti yang merangsang stimulus pengguna ruang, baik melalui pengorganisasian atau interpretasi (Walgito 1989). Selanjutnya oleh Bell (2001), persepsi ini akan menghasilkan reaksi terhadap lingkungannya yang berupa sikap yang disajikan pada diagram gambar 4 di bawah ini.

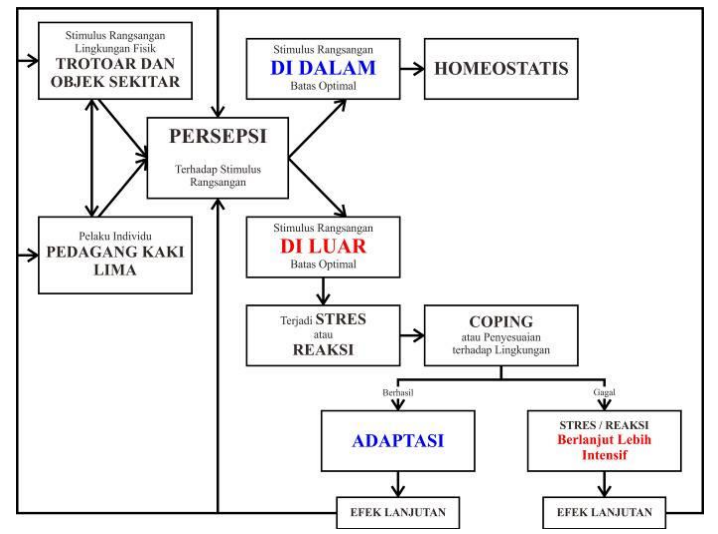

Gambar 4. Teori model eclectic, mengenai reaksi terhadap lingkungan berdasarkan persepsi Sumber: (Bell, Fisher, and Loomis 2001)

Dari teori model eclectic oleh Bell (2001) di atas, hubungan manusia dengan lingkungan diawali dengan kontak fisik individu dengan objek/properti di lingkungan sekitar. Pada kasus penelitian ini, individu adalah PKL sedangkan objek properti berupa lapak dan segala kebutuhan berdagang yang berada di trotoar. Objek disini tampil dengan segala kemanfaatannya dan 
individu muncul dengan sifat individualnya. Sifat individual diartikan sebagai faktor internal yang berupa motiv, minat, tujuan minat dan harapan dari individu (Atkinson 1983). Hasil interaksi individu manusia dengan objek di lingkungan sekitar menghasilkan Persepsi terhadap objek tersebut. Jika persepsi berada didalam batas optimal maka dapat diartikan dalam keadaan homeostatis. Homeostatis yakni keadaan seimbang yang patut dipertahankan karena memberikan kesenangan tersendiri. Sebaliknya, apabila persepsi berada di luar batas optimal, maka akan memunculkan reaksi atau stres sehingga manusia melakukan "coping" atau penyesuaian diri dengan lingkungan sekitar. Ada dua kemungkinan menurut Bell (2001), yakni:

1. Keberhasilan, berupa adaptasi atau adjustment (lingkungan yang menyesuaikan diri individu). Adaptasi sendiri memiliki tiga model (Altman 1975), adaptation by reaction yakni merubah lingkungan agar sesuai dengan keinginan, adaptation by adjusment yakni merubah perilaku manusia agar sesuai dengan lingkungan, dan adaptation by withdrawal atau lari dari lingkungan.

2. Kegagalan, yang menghasilkan stres berkepanjangan.

Karakteristik atau sifat individu berupa variabel motiv, minat, harapan, nilai-nilai, dan sikap lebih lanjut akan saling berinteraksi kemudian bersinergi dengan lingkungan akan menentukan Perilaku individu tersebut (Kuhn 1951). Fenomena Perilaku kemudian dimaknakan bentuk interaksi manusia berupa individu atau organisasi, dengan setting lingkungan fisiknya (Weisman 1981). Gagasan tersebut sesuai dengan teori model sistem perilaku lingkungan pada gambar 5.

Atribut menurut Weisman terdiri dari kesesakan, sosiabilitas, aksesibilitas, visibilitas, keamanan, dan kenyamanan (Weisman 1981). Terdapat pendapat lain mengenai atribut baik atribut yang muncul dari lingkungan atau manusia, yakni kesesakan, sosiabilitas, aksesibilitas, sensor inderawi, visibilitas, keamanan, kenyamanan, adaptabilitas, aktivitas, privasi, legabilitas, dan makna (Windley and Scheidt 1980).

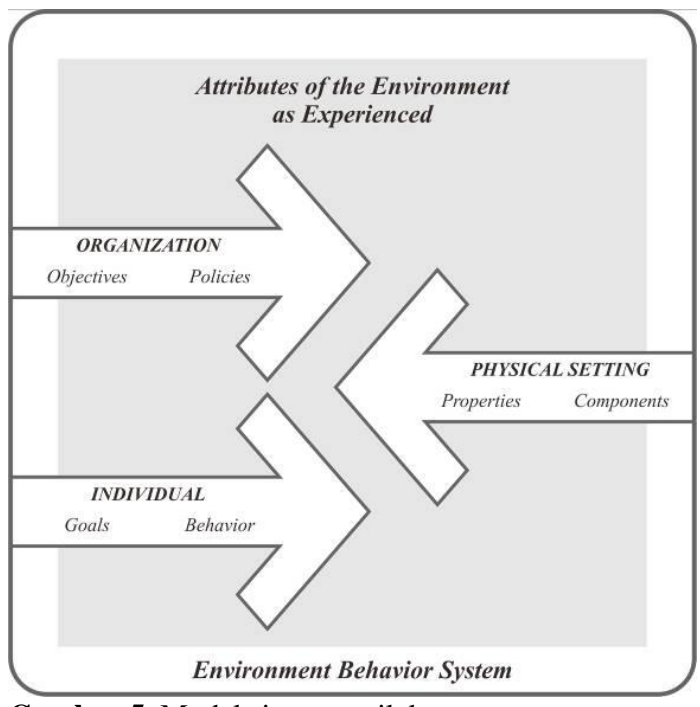

Gambar 5. Model sistem perilaku

Sumber: (Weisman 1981)

Pemilihan atribut itu sendiri harus dilihat relevansinya dengan setting fisik dan perilaku manusia di sekitarnya. Setting adalah wadah ruang fisik dimana tertuang kebiasaan sehari-hari seseorang (Haryadi 2010). Dapat diartikan juga sebagai tempat manusia berkegiatan (Rapoport 1978). Untuk memahami dan menguraikan hubungan perilaku dengan lingkungan serta menemukan atribut sebagai pengalaman yang dihasilkan, digunakanlah metode rekonseptualisasi lingkungan fisik dengan melihat sifat lingkungan dan diikuti dengan sketsa pemaknaan (Archea 1977). Salah satunya adalah metode person centered mapping, yakni pengamatan alur sirkulasi sampel manusia di area yang menjadi lokus amatan (Laurens 2004).

\section{Metode penelitian}

Untuk mendapatkan data statistik mengenai persepsi PKL terhadap kondisi trotoar koridor Jalan Pandanaran digunakan kuesioner tertutup dengan menentukan variabel bebas dan terikatnya. Variabel bebas berupa persepsi minat, tujuan, dan harapan (Lihat tabel 1). Sedangkan, variabel terikat berupa atribut yang muncul dari kondisi setting trotoar koridor Jalan Pandanaran (Lihat tabel 2).

Data statistik tersebut didukung dengan data behavior mapping yang merupakan proses pemetaan perilaku manusia yang berpola dan terjadi berulangkali pada lokasi tertentu (Sommer 
and Sommer 2001). Salah satunya berupa person centered mapping dimana pada penelitian ini bertujuan menggambarkan perilaku PKL yang didasarkan pada persepsi terhadap atribut visibilitas, aksesibilitas, keamanan, dan adaptabilitas yang dihasilkan oleh lingkungan. Dalam pelaksanaan behavior mapping menurut Michelson dan Reed yang dikutip oleh Laurens, 2004, dibatasi oleh time budget untuk memperlihatkan individu dalam menggunakan waktunya (Laurens 2004). Penelitian ini menerapkan time budget dengan rentang waktu 07.00 - 08.00, 12.00 - 13.00, dan 18.00 - 19.00. Data yang dihasilkan dari dua metode di atas, kemudian dianalisis menggunakan metode analisis statistik deskriptif dan diinterpretasi.

Tabel 1. Variabel bebas

\begin{tabular}{|c|c|c|c|}
\hline V. Bebas & Indikator & Tolo & ukur \\
\hline \multirow{6}{*}{$\begin{array}{l}\text { Persepsi } \\
\text { PKL } \\
\text { terhadap } \\
\text { keberadaan } \\
\text { trotoar } \\
\text { sebagai } \\
\text { prasarana } \\
\text { pejalan kaki }\end{array}$} & \multirow{2}{*}{ Minat } & a. & $\begin{array}{l}\text { Sebagai penghasilan } \\
\text { pokok (lokasi dan } \\
\text { media dagang untuk } \\
\text { waktu lama) }\end{array}$ \\
\hline & & b. & $\begin{array}{l}\text { Sebagai penghasilan } \\
\text { tambahan (lokasi dan } \\
\text { media dagang untuk } \\
\text { sementara) }\end{array}$ \\
\hline & \multirow[t]{2}{*}{$\begin{array}{l}\text { Tujuan } \\
\text { minat }\end{array}$} & a. & $\begin{array}{l}\text { Lapak ditata dengan } \\
\text { lengkap (layout } \\
\text { persegi/persegi } \\
\text { panjang) dekat pusat } \\
\text { keramaian }\end{array}$ \\
\hline & & b. & $\begin{array}{l}\text { Lapak ditata apa } \\
\text { adanya (layout letter } \\
\text { L) di area penyangga }\end{array}$ \\
\hline & \multirow{2}{*}{ Harapan } & & $\begin{array}{l}\text { Dimensi dan desain } \\
\text { trotoar perlu dirubah } \\
\text { (adjusment) }\end{array}$ \\
\hline & & & $\begin{array}{l}\text { Dimensi dan desain } \\
\text { trotoar dibiarkan apa } \\
\text { adanya (adaptasi) }\end{array}$ \\
\hline
\end{tabular}

Sumber: dikembangkan dari Rita L. Atkinson, 1983 (Atkinson 1983)

Tabel 2. Variabel terikat

\begin{tabular}{|c|c|c|c|}
\hline V. Terikat & Indikator & \multicolumn{2}{|c|}{ Tolok ukur } \\
\hline \multirow{5}{*}{$\begin{array}{l}\text { Atribut } \\
\text { yang } \\
\text { Muncul } \\
\text { dari } \\
\text { Setting } \\
\text { Trotoar } \\
\text { Koridor } \\
\text { Pandanaran } \\
\text { (Zona A, } \\
\text { B, dan C) }\end{array}$} & \multirow{4}{*}{ Visibilitas } & a. & $\begin{array}{l}\text { View to site (lapak } \\
\text { di tepi jalan, tidak } \\
\text { terhalang) }\end{array}$ \\
\hline & & b. & $\begin{array}{l}\text { View to site (lapak } \\
\text { di muka toko, } \\
\text { terhalang PKL lain) }\end{array}$ \\
\hline & & a. & $\begin{array}{l}\text { View from site } \\
\text { (orientasi spanduk } \\
\text { ke segala arah) }\end{array}$ \\
\hline & & b. & $\begin{array}{l}\text { View from site } \\
\text { orientasi spanduk } \\
\text { satu arah) }\end{array}$ \\
\hline & Aksesibilitas & a. & $\begin{array}{l}\text { Jauh (lapak ke } \\
\text { bahan baku) }\end{array}$ \\
\hline
\end{tabular}

\begin{tabular}{|c|c|c|}
\hline V. Terikat & Indikator & Tolok ukur \\
\hline & & $\begin{array}{l}\text { Dekat (lapak ke } \\
\text { bahan baku) }\end{array}$ \\
\hline & & $\begin{array}{l}\text { Jadi satu (pedagang } \\
\text { ke pembeli) }\end{array}$ \\
\hline & & $\begin{array}{l}\text { Terpisah (pedagang } \\
\text { be pembeli) }\end{array}$ \\
\hline & & $\begin{array}{l}\text { Mudah (akses listrik } \\
\text { a. } \\
\text { umum) }\end{array}$ \\
\hline & & $\begin{array}{l}\text { Tidak Mudah (akses } \\
\text { b. listrik umum) }\end{array}$ \\
\hline & & $\begin{array}{l}\text { Mudah (akses air } \\
\text { bersih) }\end{array}$ \\
\hline & & $\begin{array}{l}\text { b. } \begin{array}{l}\text { Sukar (akses air } \\
\text { bersih) }\end{array} \\
\end{array}$ \\
\hline & & $\begin{array}{ll}\text { a. } & \text { Aman (gerobak } \\
\text { ditinggal) }\end{array}$ \\
\hline & Keamanan & $\begin{array}{l}\text { Khawatir (gerobak } \\
\text { dibawa) }\end{array}$ \\
\hline & & a. Aman (lapak datar) \\
\hline & & $\begin{array}{l}\text { b. } \begin{array}{l}\text { Khawatir (lapak } \\
\text { miring) }\end{array} \\
\end{array}$ \\
\hline & & $\begin{array}{ll} & \begin{array}{l}\text { Bermanfaat } \\
\text { (keberadaan tiang } \\
\text { listrik) }\end{array} \\
\end{array}$ \\
\hline & & $\begin{array}{l}\text { Tidak bermanfaat } \\
\text { b. (keberadaan tiang } \\
\text { listrik) }\end{array}$ \\
\hline & Adaptaomitas & $\begin{array}{l}\text { Tidak bergeser (thdp } \\
\text { a. } \\
\text { lain) } \\
\text { lainadaan PKL } \\
\end{array}$ \\
\hline & & $\begin{array}{l}\text { Bergeser (thdp } \\
\text { b. } \\
\text { keberadaan PKL } \\
\text { lain) }\end{array}$ \\
\hline
\end{tabular}

Sumber: dikembangkan dari Weisman, 1981 (Weisman 1981)

\section{Temuan dan pembahasan}

Data statistik yang dihasilkan dari persepsi PKL terhadap trotoar koridor Jalan Pandanaran sebagai berikut (Lihat gambar 6).

Dari gambar histogram tersebut, menunjukkan persepsi minat 1 yakni berdagang sebagai penghasilan utama cenderung pada zona $\mathrm{C}$ sejumlah $17 \mathrm{PKL}$ dengan persentase 52\% $(\mathrm{N}=33)$ sedangkan, minat 2 berdagang sebagai penghasilan tambahan didominasi pada zona $\mathrm{B}$ sejumlah 4 PKL dengan persentase $3 \%(\mathrm{~N}=33)$. 


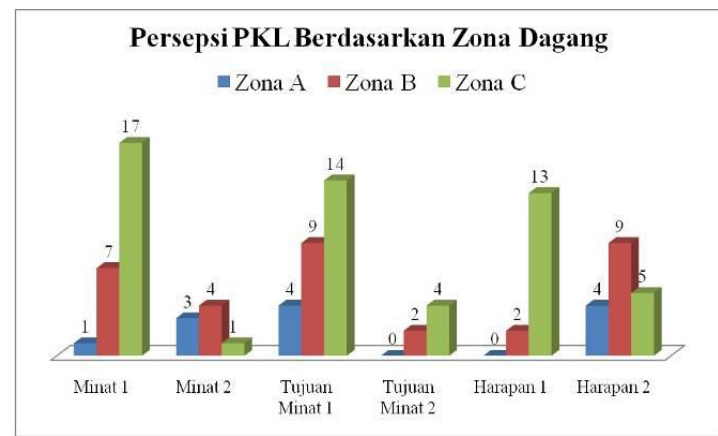

Gambar 6. Data persepsi PKL

Untuk tujuan minat 1 berupa penataan lapak dengan lengkap didominasi zona $\mathrm{C}$ sejumlah 14 PKL dengan persentase $42 \%(\mathrm{~N}=33)$ sedangkan tujuan minat 2 menata lapak dengan seadanya juga didominasi zona $\mathrm{C}$ sejumlah 4 PKL dengan persentase $12 \%(\mathrm{~N}=33)$.

Mengenai harapan 1 berupa perlunya ubahan dimensi dan desain trotoar didominasi oleh zona C dengan jumlah 13 PKL persentase 39\% ( $\mathrm{N}=33$ ), sedangkan harapan 2 bahwa trotoar hanya perlu dipertahankan didominasi oleh zona $\mathrm{B}$ dengan jumlah 9 PKL persentase $15 \%(\mathrm{~N}=33)$.

Hasil analisis dari data di atas, menunjukkan bahwa minat berdagang untuk penghasilan utama, tujuan minat penataan layout dengan lengkap serta harapan dimensi dan desain untuk diubah didominasi PKL yang berada di zona $\mathrm{C}$.

\section{Data atribut PKL}

Data statistik yang dihasilkan dari atribut PKL dari semua zona adalah sebagai berikut (Lihat gambar 7).

Grafik histogram tersebut menunjukkan untuk atribut visibilitas view to site berupa pemilihan lapak di pinggir jalan sehingga pengendara maupun pejalan kaki dapat melihat dagangan menunjukkan angka sejumlah $25 \mathrm{PKL}$, atau persentase 76\% dari 33 PKL memilih lokasi di pinggir jalan dibandingkan dengan muka toko.

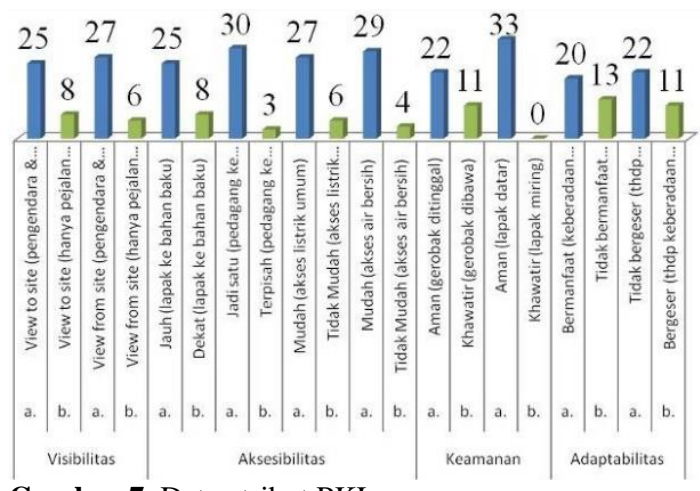

Gambar 7. Data atribut PKL

\section{Atribut visibilitas}

Grafik histogram di atas menunjukkan untuk atribut visibilitas view to site berupa pemilihan lapak di pinggir jalan, sehingga pengendara maupun pejalan kaki dapat melihat dagangan menunjukkan angka sejumlah 25 PKL, atau persentase $76 \%$ dari 33 PKL memilih lokasi di pinggir jalan dibandingkan dengan muka toko. PKL yang berdagang di pinggir jalan sebagian besar pedagang dengan shift waktu tertentu dan tidak memiliki pelanggan khusus, sehingga pembelinya random atau dari pejalan kaki yang sekadar lewat (Lihat gambar 8). Delapan PKL yang berdagang di muka toko keseluruhan adalah pedagang utama yang telah memiliki pelanggan tetap.

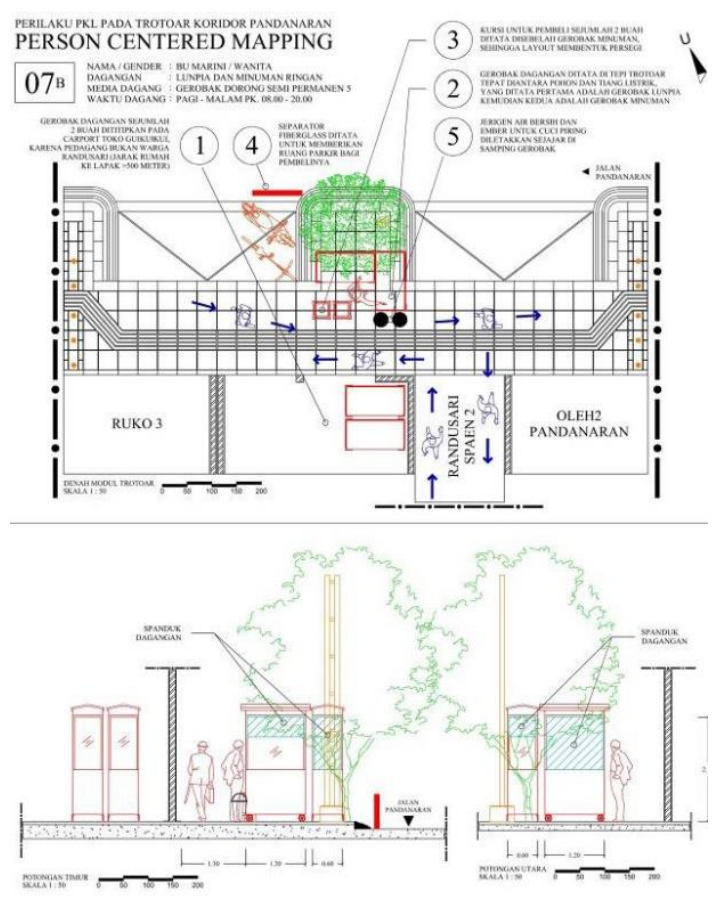




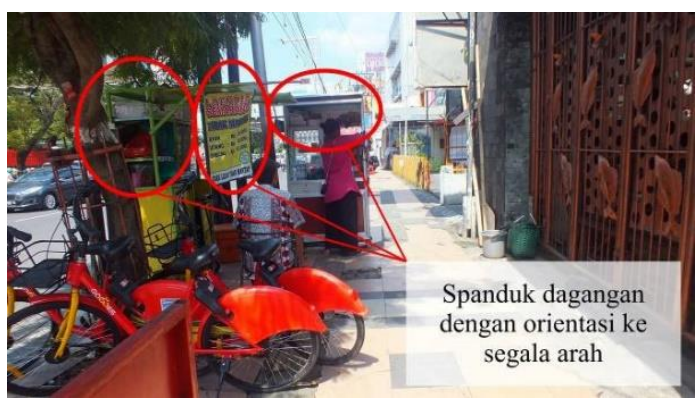

Gambar 2. Person centered mapping atribut visibilitas dan foto eksisting

Sedangkan, view from site yang berhubungan dengan orientasi pemasangan spanduk didominasi oleh pemasangan spanduk segala arah dengan angka 27 PKL dengan persentase $82 \%$. Pengguna spanduk orientasi segala arah adalah PKL yang berada di pinggir jalan. Sedangkan, PKL yang berada di muka toko menggunakan spanduk orientasi satu arah yang ditempatkan pada tiang listrik atau pohon.

\section{Atribut aksesibilitas}

Atribut aksesibilitas mengenai jarak lapak ke tempat bahan baku/produsen mayoritas jauh, dengan jumlah 25 PKL dengan persentase $76 \%$. Untuk tambahan komoditas dagangan, tidak jarang PKL mendapatkan titipan dagangan dari toko oleh-oleh yang lebih besar. Sehingga membuktikan bahwa karakter PKL baik dari komoditas dagangan hingga penataan lapak sangat erat hubungannya dengan ruang disekitarnya (Widjajanti 2012).

Indikator kedua yakni akses pedagang ke pembeli didominasi oleh akses menjadi satu sejumlah 30 PKL dengan persentase 91\% (Lihat gambar 9).

Tiga PKL yang memilih pedagang dan pembeli terpisah atau keduanya, merupakan pedagang angkringan yang hanya berdagang di waktu malam hari.

Indikator ketiga adalah kemudahan akses listrik untuk tambahan penerangan sejumlah 27 PKL dengan persentase $82 \%$, sementara 6 PKL sisanya tidak membutuhkan listrik dikarenakan menggunakan daya listrik portable. Listrik pada trotoar menggunakan stop kontak yang telah tersedia di dekat tiang listrik atau menggunakan listrik dari toko atas izin dari yang bersangkutan.

Indikator terakhir adalah kemudahan air bersih sejumlah 29 PKL dengan persentase $88 \%$. Air bersih didapatkan dari toko terdekat atas seizin pengelola toko. Sedangkan, yang tidak menggunakan air bersih dari toko memilih membawa air bersih dari rumah menggunakan ember.
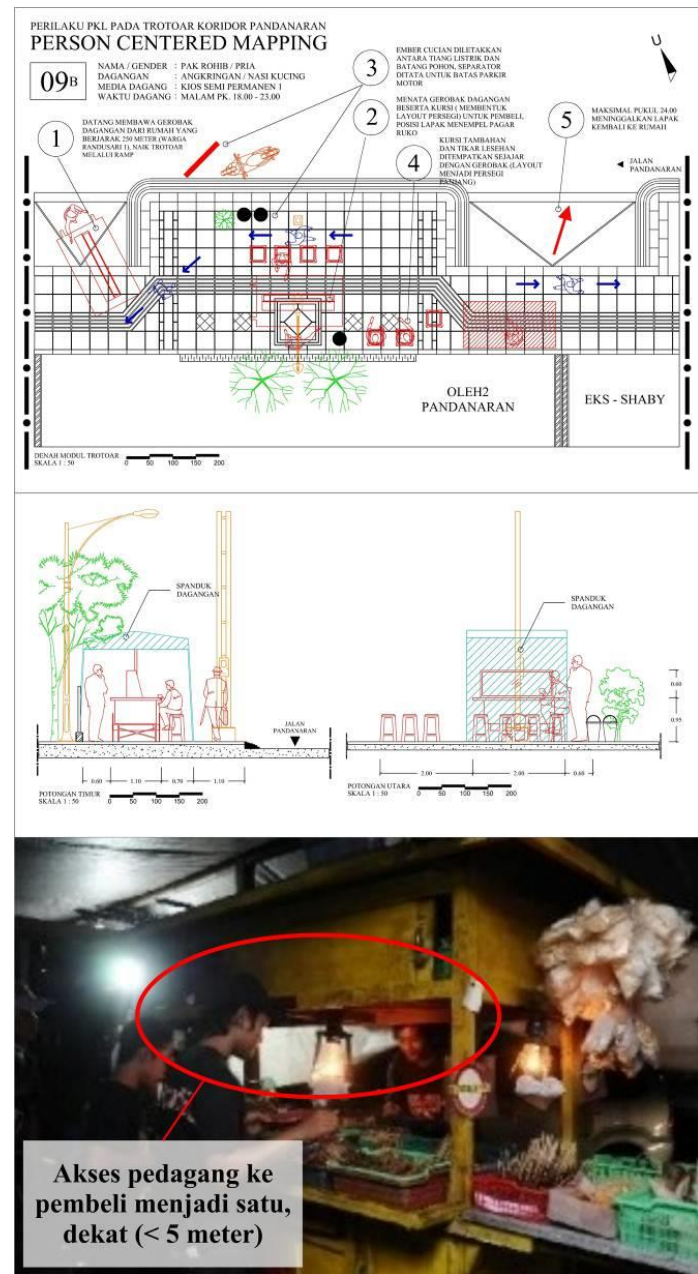

Gambar 3. Person centered mapping atribut aksesibilitas dan foto eksisting

\section{Atribut keamanan}

Atribut keamanan terdapat dua indikator. Indikator pertama mengenai rasa aman para pedagang atas gerobak bila ditinggal di lapak seusai berdagang sejumlah 22 PKL dengan presentase $67 \%$.

Pedagang sisanya memilih untuk membawa pulang gerobak atau menitipkan gerobak di gang sempit dekat rumah (Lihat gambar 10). 


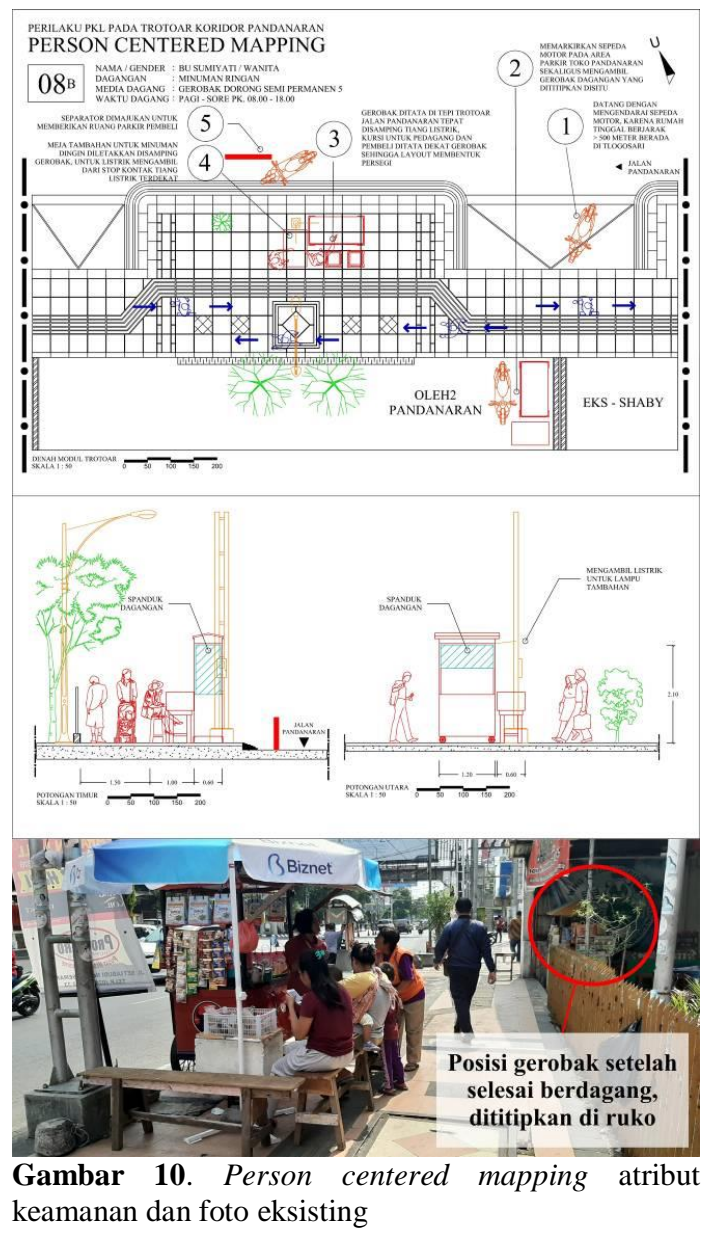

PKL yang meninggalkan gerobak di trotoar, menggunakan keberadaan tiang listrik atau pohon sebagai media pengaman. Dengan cara diikatkan menggunakan rantai kemudian dikunci.

Indikator kedua yakni rasa aman mengenai elevasi lapak, PKL takut apabila sedang berdagang gerobak dagangan miring kemudian jatuh. Serempak ke 33 pedagang menyatakan bahwa trotoar koridor Pandanaran aman dan datar dengan persentase $100 \%$.

Atribut adaptabilitas

Atribut terakhir adalah adaptabilitas atau kemampuan lingkungan mengakomodasi pola perilaku baru.

Menurut Woodworth, ada empat kemungkinan yakni individu memanfaatkan, ikut serta, menyesuaikan diri, atau menentang lingkungannya (Gerungan 2000). Indikator pertama yang terlihat dari gambar di bawah ini adalah keberadaan street furniture tiang listrik yang dimanfaatkan oleh PKL (Lihat gambar 11).

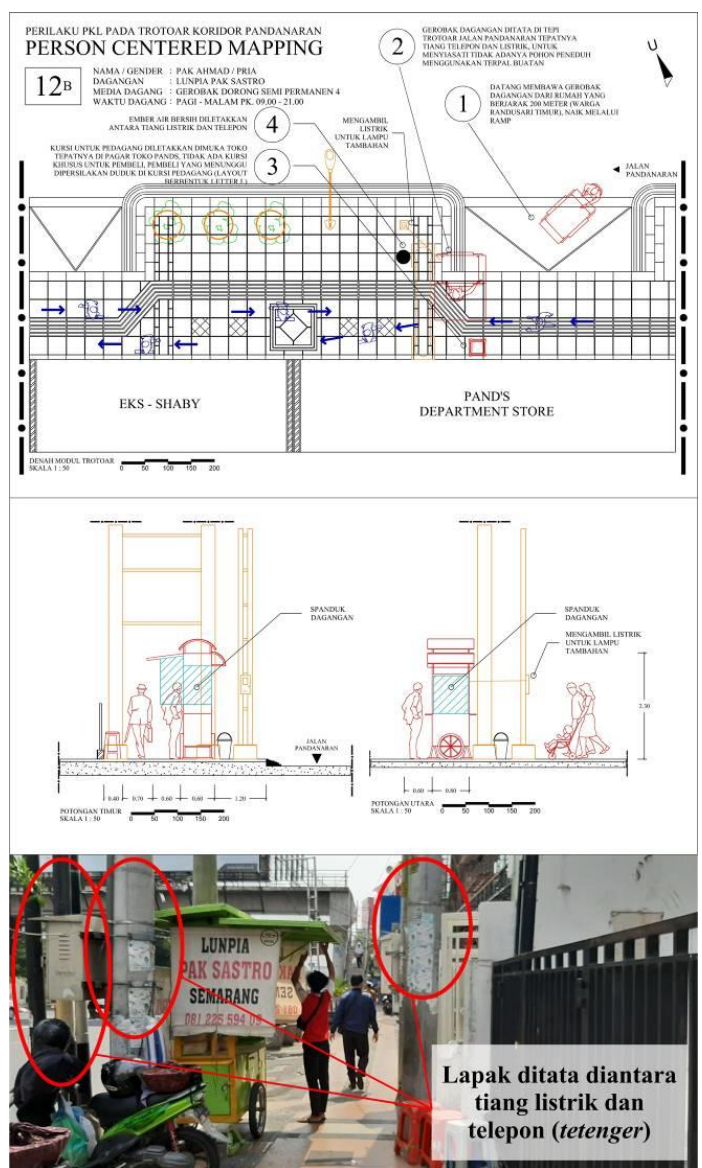

Gambar 11. Person centered mapping atribut adaptasi dan foto eksisting

Street furniture disini adalah elemen yang ditata secara kolektif untuk kenyamanan pengguna jalan (Harris, Dines, and Fishbeck 1988).

Sejumlah 20 PKL atau persentase 61\% menyatakan bahwa selain untuk sumber listrik, tiang listrik berguna untuk tetenger atau penanda lapak masing-masing PKL.

Indikator kedua adalah lapak yang tetap/tidak bergeser terhadap lapak PKL lain yang telah ada, terjadi adaptasi dengan lapak yang lebih dahulu buka. Sejumlah 22 PKL dengan persentase 67\% menyatakan bahwa lapaknya tidak bergeser karena memiliki tetenger. Tetenger atau patokan/penanda bagi PKL berupa street furniture tiang listrik, tiang telepon, vegetasi pohon dan tanaman perdu, bahkan prasarana halte maupun JPO. Sisanya 11 PKL memberikan toleransi bagi sesama PKL apabila lapaknya bergeser sedikit. 


\section{Kesimpulan}

Dari hasil analisis terhadap penelitian ini, maka terungkap bahwa persepsi atribut para PKL memiliki keterkaitan dengan trotoar koridor jalan Pandanaran. Hal tersebut dibuktikan dengan adanya objek pada trotoar yang dianggap memiliki kekuatan properti untuk mewadahi tuntutan atribut PKL. Seluruh street furniture dan prasarana seperti JPO dipersepsikan PKL menjadi sarana memasang spanduk, patokan lapak, hingga pengaman gerobak apabila ditinggal. Atribut visibilitas, aksesibilitas, keamanan, dan adaptabilitas hampir semuanya terpenuhi kecuali atribut aksesibilitas pada indikator akses lapak ke bahan baku.

Adapun beberapa rekomendasi untuk perancangan trotoar dilihat dari sudut pandang PKL dengan tidak melupakan hak utama pejalan kaki antara lain: (1) Pemerataan spot khusus PKL secara merata (tidak memusat); (2) Dalam penentuan standar dimensi lapak PKL, keberadaan pembeli dan pejalan kaki juga dijadikan acuan; (3) Dimensi trotoar perlu dikaji ulang serta desain trotoar perlu adanya pembaharuan; (4) Perlu adanya penataan spanduk masing - masing gerobak karena berdampak pada estetika ruang kota; (5) Perlu adanya penanaman vegetasi pohon baik bermanfaat untuk tetenger sekaligus penghijauan kota; (6) Pembuatan ruang parkir dan loading - unloading khusus PKL, sehingga proses bongkar muat tidak mengganggu sirkulasi trotoar; (7) Pengoptimalan penggunaan kendaraan umum untuk mencapai lokasi lapak.

\section{Referensi}

Altman, Irwin. 1975. The Environment and Social Behavior: Privacy, Personal Space, Territory, Crowding. California: Brooks/Cole Publishing Company.

Archea, John. 1977. 'The Place of Architectural

Factors in Behavioral Theories of Privacy'. Journal of Social Issues 33 (3): 116-37. https://doi.org/10.1111/j.1540-

4560.1977.tb01886.x.

Atkinson, Rita L. 1983. The Hidden Dimention. Edited by New York Doubleday. New York.

Bell, Paul A., Jeffrey D. Fisher, and Ross J. Loomis. 2001. Environmental Psychology. Philadelphia: WB Saunders Company.

Fryer, Donald W. 1982. 'T. G. McGee and Y. M. Yeung, Hawkers in Southeast Asian Cities: Planning for the Bazaar Economy. International Development Research Center, Ottawa, 1977. Pp. 139'. African and Asian Studies $\quad 17 \quad$ (3): $\quad 314-16$. https://doi.org/10.1163/156852182X00967.

Gerungan, W. A. 2000. Psikologi Sosial. Bandung: Refika Aditama.

Grigg, Neil S. 1988. Infrastructure Engineering and Management. 1st ed. Australia: WileyInterscience.

Harris, Charles W., Nicholas T. Dines, and Gary M. Fishbeck. 1988. Time-Saver Standards for Landscape Architecture: Design and Construction Data. New York: McGraw-Hill.

Haryadi, Setiawan B. 2010. Arsitektur, Lingkungan Dan Perilaku: Pengantar Ke Teori Metodologi Dan Aplikasi. Yogyakarta: Gadjah Mada University Press.

Kuhn, Manford H. 1951. 'LEWIN, KURT: Field Theory of Social Science: Selected Theoretical Papers'. The ANNALS of the American Academy of Political and Social Science 276 (1): $146-47$. https://doi.org/10.1177/00027162512760013 5.

Laurens, Joyce Marcella. 2004. Arsitektur Dan Perilaku Manusia. Jakarta: Grasindo.

Mberu, Yuliana Bhara, and Yohanes Djarot Purbadi. 2018. 'Makna Ruang Jalan Di Kota Lama Kupang Menurut Pengguna Ruang Pedagang Informal Dan Formal'. ARTEKS : Jurnal Teknik Arsitektur 3 (1): 79-100. https://doi.org/10.30822/arteks.v3i1.56.

McGee, T. G., and Y. M. Yeung. 1977. Hawkers in Southeast Asian Cities: Planning for the Bazaar Economy. Ottawa: International Development Research Center. http://hdl.handle.net/10625/1435.

Rapoport, A. 1978. Human Aspects of Urban Form: Toward A Man-Environment Approach to Urban Form \& Design. Human Aspects of Urban Form: Toward A Man-Environment 
Approach to Urban Form \& Design. Newy York: Pergamon Press.

Sarwono, Sarlito Wirawan. 1992. Psikologi Lingkungan. Jakarta: Grasindo.

Sirvani, Hamid. 1985. The Urban Design Process. New York: Van Nostrand Reinhold Company.

Sommer, Robert, and Barbara Sommer. 2001. A Practical Guide to Behavioral Research: Tools and Techniques. 5th ed. New York: Oxford University Press.

Walgito, Bimo. 1989. Pengantar Psikologi Umum. Yogyakarta: Andi Offset.

Wardianto, Gatoet, Eko Budihardjo, Eko Budihardjo, and Eddy Prianto. 2012. 'Tuntutan Atribut Persepsi Pejalan Kaki Pada Penggunaan Jembatan Penyeberangan Di Jatingaleh Semarang'. Dinamika TEKNIK $\begin{array}{llll}\text { SIPIL } & 12 & \text { (2): 194-200. }\end{array}$ https://publikasiilmiah.ums.ac.id/bitstream/ha ndle/11617/2024/_16_ Gatot-UNDIP _ok_.pdf?sequence $=1$ \&isAllowed=y.

Weisman, G. D. 1981. 'Modelling Environtment Behavior System. A Brief Note'. Journal of Man-Environment Relations 1 (2): 32-41.

Widjajanti, Retno. 2012. 'Karakteristik Aktivitas Pedagang Kaki Lima Pada Kawasan Komersial Di Pusat Kota, Studi Kasus: Simpang Lima, Semarang'. TEKNIK 30 (3): 162-70.

https://doi.org/https://doi.org/10.14710/teknik .v30i3.1892.

Windley, Paul G., and Rick J. Scheidt. 1980. 'The Well-being of Older Persons in Small Rural Towns: A Town Panel Approach'. Educational Gerontology 5 (4): 355-73. https://doi.org/10.1080/0360127800050403. 